\title{
A MODEL FOR CALCULATING THE DENSITY OF AQUEOUS MULTICOMPONENT ELECTROLYTE SOLUTIONS
}

\author{
ELIZABETH J. LAM ${ }^{1}$, MIGUEL N. ALVAREZ², MARÍA E. GALVEZI AND EDUARDO B. ALVAREZ \\ ${ }^{1}$ Department of Chemical Engineering, Faculty of Engineering and Geological Sciences, \\ Universidad Católica del Norte, Avenida. Angamos 0610, Antofagasta, Chile \\ ${ }^{2}$ Department of Chemical Engineering, Faculty of Engineering, Universidad de Antofagasta, Campus Coloso s/n, Antofagasta, Chile \\ (Received: 9 November 2006 - Accepted: 13 November 2007)
}

\begin{abstract}
A method is presented for calculating the densities of simple and multicomponent aqueous saline solutions.

A total of 38 parameters were obtained for anions and cations which allowed predicting their density in aqueous solution. The proposed method is based on the model of Hörsak and Slama ${ }^{1}$ applicable to simple 1:1 aqueous electrolyte solutions which in the present study was extended to multicomponent systems and for any type of salt. Seventeen aqueous systems containing 2,3 , and 4 salts were studied, obtaining excellent results when compared with the experimental values. The total relative mean standard deviation obtained was $0.08 \%$. The proposed method used adjustable parameters, which are obtained beginning from experimental data from systems containing a single salt. Two parameters are required for each ion present in the aqueous solution
\end{abstract}

Keywords: Density, multicomponent systems, aqueous solutions, electrolytes.

\section{INTRODUCTION}

Northern Chile is a zone typified by the presence of about 75 basins containing saline deposits, with the Atacama Salt Deposit being one of the most economically important. Its deposits are high in potassium, magnesium, calcium, boron, lithium, and sulfate, and in brines saturated with sodium chloride. The brines from the Atacama Salt Deposit are well known for their yields of boric acid, lithium carbonate, and potassium chloride. The density of simple and multicomponent electrolyte systems play an important role in diverse fields of endeavor, including chemistry and chemical engineering, recovery of oils, oceanography, steam plants ${ }^{2}$. Other practical applications include calculations of material balances in crystallizers and evaporators used for the extraction of inorganic salts, precipitation processes, and crystallization in geothermal energy systems, water desalinization, control of water pollution, salting in and salting out effects in extraction and distillation in food processing 3,4

Data on the density of multicomponent saline systems are scarce in the literature ${ }^{5}$. Nevertheless, numerous empirical models have been developed and published in the literature for application in the description of aqueous systems containing a single salt ${ }^{6}$. Unfortunately very few models have been evaluated for applications which have acceptable precision for predicting the densities of solutions in systems containing more than one salt ${ }^{7}$. Predictive methods which use experimental information on simple systems for predicting the properties of multicomponent systems have been of great practical use ${ }^{8}$, particularly in conditions dealing with high salt concentrations.

Based on its great practical importance, the thermodynamic properties of aqueous saline systems have been widely studied both from the theoretical and experimental perspective. Theoretical approximations for the volumetric properties have been generally limited to solutions of moderate to dilute concentration, requiring numerical calculations which are generally tedious and/or complicated. Semi-empirical estimates are simpler, but require adjustable parameters obtained from specific experimental data ${ }^{9}$.

\section{A MODEL FOR THE CALCULATION OF DENSITY}

Hörsak and Slama ${ }^{1}$ presented a model for estimating the density of simple 1:1 aqueous solutions of electrolytes based on the concept of apparent molar volume which involves a separation of the molar volume parameters of the salt in order to justify the deviation of the additive property of the molar volume of the solution and the anionic and cationic contributions.

The model proposed by Hörsak and Slama has been extended in the present study in order to make density correlations in terms of multicomponent ionic solutions applicable to any type of salt, that is ; 1:1, 1:2, 2:1, 1:3, 3:1, etc.
The density ( $\rho$ ) of aqueous saline solutions can be expressed in terms of molar volume $(v)$ by the following expression:

$$
\rho=\frac{M_{a v}}{v}
$$

Where $M_{a v}$ represents the average of the molar mass of the saline solution, which is related to the molar fractions and the molecular weights of the ions ( $i$ ), and of water, symbolized as $x_{i}, M_{i}, x_{w}$ and $M_{w}$, respectively, determined as:

$$
M_{a v}=\sum_{i=1}^{N_{I O N}} x_{i} M_{i}+x_{w} M_{w}
$$

$\mathrm{N}_{\text {ION }}$ symbolizes the number of lines present in solution with (i ) representing each ion, with (w) as the solvent, in this case water.

Equation (2) can be rewritten as:

$$
M_{a v}=\sum_{i=1}^{N_{I O N}} x_{i} M_{i}+\left(1-\sum_{i=1}^{N_{I O N}} x_{i}\right) M_{w}
$$

Hörsak and Slama ${ }^{1}$ propose the following equation for determining the molar volume of simple aqueous saline solutions based on the additive principal of ionic properties:

$$
v=v_{s}^{o} \cdot x_{s}+v_{w}^{o}\left(1-x_{s}\right)+\alpha \cdot x_{s} \frac{1-x_{s}}{1+x_{s}}
$$

Where $(\alpha)$ is an empirical parameter, $v_{s}^{o}$ and $v_{w}^{o}$ are the molar volume of the salt, and of water, respectively, and $x_{s}$ is the molar fraction of the electrolyte given by equation (5):

$$
x_{s}=\frac{n_{s}}{n_{w}+v n_{s}}
$$

Where $n_{s}$ represents the number of moles electrolyte and $n_{w}$ symbolizes the number of moles of water, both per $1000 \mathrm{~g}$ of water 
$n_{w}=\frac{1000}{M_{w}}=55.51 \mathrm{~mol} \quad()$, and $v$ represents the total number of moles of ions formed from the dissociation of the salt $\left(v=v_{c}+v_{A}\right)$ when $1 \mathrm{~mol}$ of electrolyte CA becomes completely dissociated.

In equation (4) the first term represents the contribution of the salt to the volume of the solution, the second represents the contribution of the water, and a third term represents the deviation in the volume of the water due to the interaction of the ions with the water. The parameter $\alpha$ describes the change in the volume of the water in the vicinity of the ion ${ }^{8}$.

The parameters $v_{s}^{o}$ and $\alpha$ are better represented in equation (4) by the contribution of a simple ion, more than by the parameters of the salt. In this way the molar volume of the solution can be expressed as:

$v=\left(v_{C}^{o}+v_{A}^{o}\right) \cdot x_{s}+\left(1-x_{s}\right)\left[v_{w}^{o}+\left(\alpha_{c}+\alpha_{A}\right) \cdot \frac{x_{s}}{\left(1+x_{s}\right)}\right](6)$

Equation (6) is applicable to binary saline solutions containing $\mathrm{n}_{\mathrm{s}} \mathrm{m}$ ' of the CA salt (completely dissociated) in one $\mathrm{kg}$ of water. $v_{A}^{o}$ and $v_{C}^{o}$ are anionic and cationic empirical parameters, respectively, both of which are tabulated in Table 2, along with their parameters representing the ionic molar volume.

The objective of the present study was to extend equation (6) to multicomponent systems. The first modification consisted of using molar ionic fractions instead of molar fractions for the salts. This variation allowed use of the model for any type of salt, which as stated above was limited only to $1: 1$ type salts. There was no requirement to specify the ionic increase due to the dissociation of the type of salt $(1: 1,2: 1,3: 2$, etc.) in the equation. Due to this it was necessary to separate $x_{s}$ of the salt in equation (6) in terms of the cationic and anionic molar fraction. Equation (6) was therefore rewritten as:

$$
\begin{gathered}
v=v_{C}^{o} \cdot x_{C}+v_{A}^{o} \cdot x_{A}+v_{w}^{o} \cdot\left(1-x_{A}-x_{C}\right)+\left(\alpha_{C} \cdot x_{C}+\alpha_{A} \cdot x_{A}\right) \cdot \frac{\left(1-x_{A}-x_{C}\right)}{\left(x_{A}+x_{C}+x_{W}\right)} \\
x_{w}=1-x_{A}-x_{C}
\end{gathered}
$$

Combining equations (7) and (8) we obtained the following expression:

$$
v=v_{C}^{o} \cdot x_{C}+v_{A}^{o} \cdot x_{A}+v_{w}^{o} \cdot x_{w}+\left(\alpha_{C} \cdot x_{C}+\alpha_{A} \cdot x_{A}\right) \cdot x_{w}(9)
$$

Where $x_{A}, x_{C}$ and $x_{w}$ respectively represent the anionic, cationic and water fractions. All the preceding equations are applicable only to aqueous systems containing a single salt. Equation (9) is expressed in terms of the ionic composition of the aqueous solution. By extending its application to multicomponent systems through equation (10):

$$
v=\sum_{i=1}^{N_{\text {ION }}} v_{i}^{o} \cdot x_{i}+v_{w}^{o} \cdot\left(1-\sum_{i=1}^{N_{I O N}} x_{i}\right)+\sum_{i=1}^{N_{\text {ION }}} \alpha_{i} \cdot x_{i} \cdot\left(1-\sum_{i=1}^{N_{\text {ION }}} x_{i}\right)
$$

and substituting equations (3) and (10) in equation (1) we obtain:

$$
\rho=\frac{\sum_{i=1}^{N_{\text {ION }}} x_{i} M_{i}+\left(1-\sum_{i=1}^{N_{\text {ION }}} x_{i}\right) M_{w}}{\sum_{i=1}^{N_{\text {ON }}} v_{i}^{o} \cdot x_{i}+v_{w}^{o} \cdot\left(1-\sum_{i=1}^{N_{\text {OON }}} x_{i}\right)+\sum_{i=1}^{N_{\text {OON }}} \alpha_{i} \cdot x_{i} \cdot\left(1-\sum_{i=1}^{N_{\text {ONN }}} x_{i}\right)}
$$

aqueous systems, that is, two ions in solution ( $N_{I O N}=2$ ), in equation (11).

It is recommendable to use the greatest amount of experimental information on densities for a great diversity of binary systems at constant temperature and pressure in order to represent the ion-ion interaction of the parameters of the model. The information for the same ion may come from different salts which contain the ion, thus contributing to the improvement of the information on given ions, and increasing the confidence in the parameters.

\section{RESULTS}

Equation (11) was applied to data from 81 binary systems at $298.15 \mathrm{~K}$. The parameters $v_{i}^{o}$ and $\alpha_{i}$ were determined for 38 ions (17 anions and 21 cations), for which there theoretically exist $(17 \times 21)=357$ possible salts of $(17+21)=38$ different ions. This aspect is of great importance in future construction of the database. The parameters were calculated minimizing the error squared of all the data obtained at $25^{\circ} \mathrm{C}$.

The adjustable parameters $v_{i}^{o}$ and $\alpha_{\mathrm{i}}$ in equation (11) are specific for each ion. They were obtained by using the method of least squares on experimental data on the density of aqueous systems containing a single salt at

$298.15 \mathrm{~K}$, minimizing the following sum of squares at each experimental point:

$$
O . F .=\sum_{i=1}^{N_{D A T A}}\left(\rho_{\exp }-\rho_{e q .11}\right)_{i}^{2}
$$

The parameters obtained in the fits using equation (12) are shown in Table 2. All the parameters are temperature-dependent.

Table 3 shows the deviation obtained in the prediction of the density for 81 binary aqueous saline systems, and Table 4 contains 15 multicomponent systems containing between three and five components with their respective absolute deviations as obtained by applying the method proposed in this study. Equation (11), developed in the present study predicted the densities of the multicomponent systems with an average deviation of less than $0.11 \%$ compared with the experimental values for all systems evaluated, excepting the $\mathrm{CaCl}_{2}-\mathrm{KCl}-\mathrm{MgCl}_{2}-\mathrm{NaCl}-\mathrm{H}_{2} \mathrm{O}$ system. In Tables 3 and $4, \mathrm{~N}_{\mathrm{DATA}}$ represents the number of experimental points, $I_{\max }$ is the maximum ionic strength, $\% \mathrm{AD}$ represents the average percent deviation in density, which is defined as:

$$
\% A D=\frac{100 \cdot \sum_{i=1}^{N_{D A T A}}\left[\rho_{\exp }-\boldsymbol{\rho}_{e q .11} \mid / \boldsymbol{\rho}_{\exp }\right]}{N_{D A T A}}
$$

\section{Comparison with predictive methods}

The results obtained with the proposed method were compared with those obtained by three models available in the literature, including those of Patwardhan and Kumar ${ }^{8}$, Theilander and Grén ${ }^{10}$ and Pitzer as modified by $\mathrm{Kumar}^{11}$, who obtained good results for multicomponent systems. Table 5 shows the total average percent deviations for various aqueous systems.
Equation (11) can be applied to aqueous systems containing $\mathrm{n}$ ions in the solutions, requiring the values for

$N_{I O N}$ parameters of $v_{i}^{o}$ and $N_{I O N}$ parameters for $\alpha_{1}$ for the prediction, which can be obtained beginning with the information on the densities of binary 
J. Chil. Chem. Soc., 53, No 1 (2008)

Table 1. Ionic network for 81 binary systems at $298.15 \mathrm{~K}$

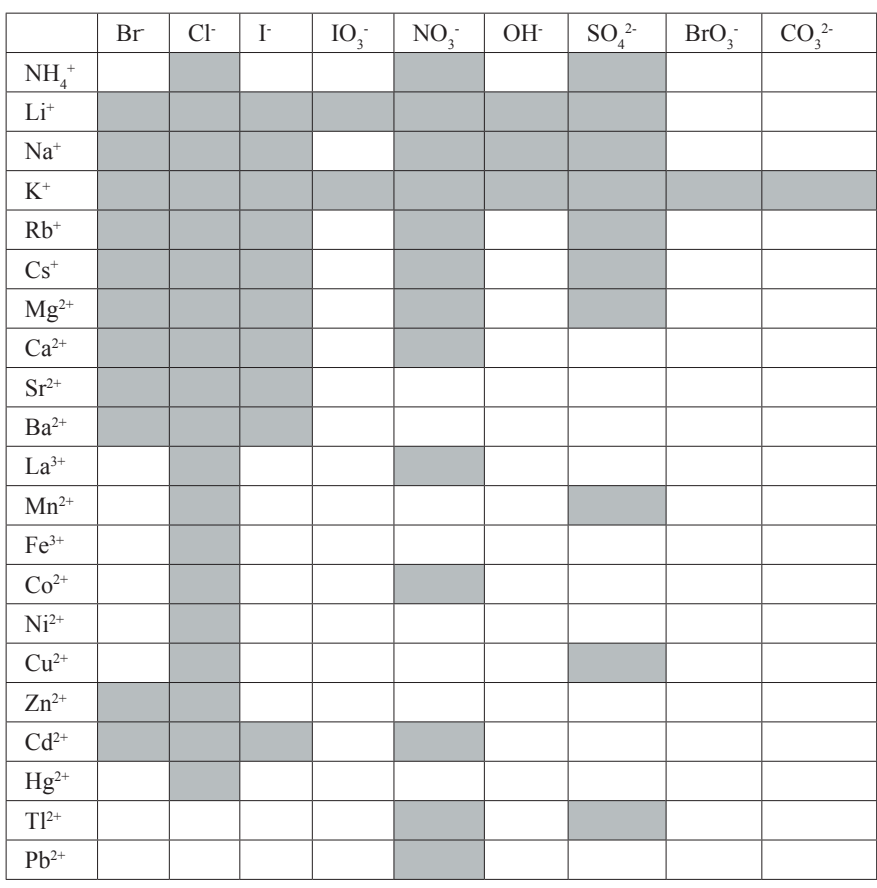

\begin{tabular}{|l|l|l|l|l|l|l|l|l|}
\hline & $\mathrm{ClO}_{3}^{-}$ & $\mathrm{ClO}_{4}^{-}$ & $\mathrm{HCO}_{3}^{-}$ & $\mathrm{H}_{2} \mathrm{PO}_{4}^{-}$ & $\mathrm{HSO}_{4}^{-}$ & $\mathrm{N}_{3}^{-}$ & $\mathrm{MoO}_{4}^{2-}$ & $\mathrm{SO}_{3}^{2-}$ \\
\hline $\mathrm{NH}_{4}^{+}$ & & & & & & & & \\
\hline $\mathrm{Li}^{+}$ & & & & & & & & \\
\hline $\mathrm{Na}^{+}$ & & & & & & & & \\
\hline $\mathrm{K}^{+}$ & & & & & & & & \\
\hline $\mathrm{R} \mathrm{b}^{+}$ & & & & & & & & \\
\hline $\mathrm{Cs}^{+}$ & & & & & & & & \\
\hline $\mathrm{Mg}^{2+}$ & & & & & & & & \\
\hline $\mathrm{Ca}^{2+}$ & & & & & & & & \\
\hline $\mathrm{Sr}^{2+}$ & & & & & & & & \\
\hline $\mathrm{Ba}^{2+}$ & & & & & & & & \\
\hline $\mathrm{La}^{3+}$ & & & & & & & & \\
\hline $\mathrm{Mn}^{2+}$ & & & & & & & & \\
\hline $\mathrm{Fe}^{3+}$ & & & & & & & & \\
\hline $\mathrm{Co}^{2+}$ & & & & & & & & \\
\hline $\mathrm{Ni}^{2+}$ & & & & & & & & \\
\hline $\mathrm{Cu}^{2+}$ & & & & & & & & \\
\hline $\mathrm{Zn}^{2+}$ & & & & & & & & \\
\hline $\mathrm{Cd}^{2+}$ & & & & & & & & \\
\hline $\mathrm{Hg}^{2+}$ & & & & & & & & \\
\hline $\mathrm{Tl}^{2+}$ & & & & & & & & \\
\hline $\mathrm{Pb}^{2+}$ & & & & & & & & \\
\hline
\end{tabular}

Table 2. Parameters for the calculation of ionic densities at 298.15 K.

\begin{tabular}{|c|c|c|}
\hline Cation & $v_{i}^{o}, \mathbf{c m}^{3} \mathbf{m o}^{\mathrm{l}-1}$ & $\alpha_{i}, \mathbf{c m}^{3} \mathrm{~mol}^{-1}$ \\
\hline $\mathrm{Ba}^{2+}$ & 18.3023 & -5.1552 \\
\hline $\mathrm{Ca}^{2+}$ & 25.1865 & -22.3772 \\
\hline $\mathrm{Cd}^{2+}$ & 9.8123 & 1.4568 \\
\hline $\mathrm{Co}^{2+}$ & 7.7433 & -10.5132 \\
\hline $\mathrm{Cs}^{+}$ & 34.4534 & -2.6230 \\
\hline $\mathrm{Cu}^{2+}$ & 30.4567 & -34.6929 \\
\hline $\mathrm{Fe}^{3+}$ & 11.8134 & -7.3003 \\
\hline $\mathrm{Hg}^{2+}$ & 15.3070 & 15.1201 \\
\hline $\mathrm{K}^{+}$ & 27.0279 & -8.0763 \\
\hline $\mathrm{La}^{3+}$ & 31.1914 & -32.9634 \\
\hline $\mathrm{Li}^{+}$ & 8.4351 & 0.0655 \\
\hline $\mathrm{Mg}^{2+}$ & 19.4707 & -18.8749 \\
\hline $\mathrm{Mn}^{2+}$ & 0.0000 & 6.6409 \\
\hline $\mathrm{NH}_{4}^{+}$ & 24.6421 & 2.8238 \\
\hline $\mathrm{Na}^{+}$ & 14.6883 & -5.9081 \\
\hline $\mathrm{Ni}^{+}$ & 17.2824 & -25.0728 \\
\hline $\mathrm{Pb}^{2+}$ & 94.0885 & -86.8831 \\
\hline $\mathrm{Rb}^{+}$ & 30.2399 & -5.7210 \\
\hline $\mathrm{Sr}^{2+}$ & 38.5117 & -35.5831 \\
\hline $\mathrm{Tl}^{+}$ & 10.9815 & 10.3291 \\
\hline $\mathrm{Zn}^{2+}$ & 40.1139 & -34.5036 \\
\hline
\end{tabular}

\begin{tabular}{|c|c|c|}
\hline Anion & $v_{i}^{o}, \mathbf{c m}^{3} \mathbf{m o}^{\mathrm{l}-1}$ & $\alpha_{i}, \mathbf{c m}^{3} \mathbf{m o l}^{-1}$ \\
\hline $\mathrm{Br}$ & 26.0512 & -9.4688 \\
\hline $\mathrm{BrO}_{3}^{-}$ & 13.4392 & 13.1391 \\
\hline $\mathrm{CO}_{3}^{2-}$ & 44.8606 & -61.8929 \\
\hline $\mathrm{Cl}^{-}$ & 23.5130 & -14.6221 \\
\hline $\mathrm{ClO}_{3}^{-}$ & 12.6994 & 12.6882 \\
\hline $\mathrm{ClO}_{4}^{-}$ & 46.1001 & -13.2870 \\
\hline $\mathrm{HCO}_{3}^{-}$ & 7.6564 & 7.2686 \\
\hline $\mathrm{H}_{2} \mathrm{PO}_{4}^{-}$ & 23.0551 & 4.5946 \\
\hline $\mathrm{HSO}_{4}^{-}$ & 76.6467 & -52.8580 \\
\hline $\mathrm{I}^{-}$ & 36.5122 & -9.8899 \\
\hline $\mathrm{IO}_{3}^{-}$ & 66.4296 & -47.5567 \\
\hline $\mathrm{MoO}_{4}^{2-}$ & 81.2460 & -65.2988 \\
\hline $\mathrm{N}_{3}^{-}$ & 23.6464 & -5.1772 \\
\hline $\mathrm{NO}_{3}^{-}$ & 36.3809 & -16.0250 \\
\hline $\mathrm{OH}^{-}$ & 17.2940 & -29.3781 \\
\hline $\mathrm{SO}_{3}^{2-}$ & 59.1677 & -63.8203 \\
\hline $\mathrm{SO}_{4}^{2-}$ & 69.4141 & -65.8818 \\
\hline
\end{tabular}


Table 3. Deviations in the prediction of the density for electrolytes in aqueous solution at $298.15 \mathrm{~K}$.

\begin{tabular}{|c|c|c|c|c|c|c|c|}
\hline SALT & $\mathbf{N}_{\text {DATA }}$ & $\begin{array}{c}\mathbf{I}_{\mathrm{MAX}} \\
\mathrm{mol} \mathrm{kg}^{-1}\end{array}$ & $\% \mathrm{AD}$ & Salt & $\mathbf{N}_{\text {DATA }}$ & $\begin{array}{c}\mathbf{I}_{\mathrm{MAX}} \\
\mathrm{mol} \mathrm{kg}^{-1}\end{array}$ & $\%$ AD \\
\hline${ }^{12} \mathrm{BaBr}_{2}$ & 14 & 2.24 & 0.10 & ${ }^{12,13} \mathrm{KNO}_{3}$ & 21 & 3.12 & 0.05 \\
\hline${ }^{12,13} \mathrm{BaCl}_{2}$ & 20 & 1.69 & 0.12 & ${ }^{16} \mathrm{KOH}$ & 11 & 3.02 & 0.07 \\
\hline${ }^{12} \mathrm{BaI}_{2}$ & 18 & 3.84 & 0.08 & ${ }^{12} \mathrm{~K}_{2} \mathrm{SO}_{4}$ & 6 & 0.64 & 0.15 \\
\hline${ }^{12} \mathrm{CaBr}_{2}$ & 16 & 5.00 & 0.08 & ${ }^{13} \mathrm{LaCl}_{3}$ & 8 & 3.00 & 0.16 \\
\hline${ }^{12,13,14} \mathrm{CaCl}_{2}$ & 28 & 4.98 & 0.07 & ${ }^{18} \mathrm{La}\left(\mathrm{NO}_{3}\right)_{2}$ & 9 & 2.05 & 0.13 \\
\hline${ }^{12} \mathrm{CaI}_{2}$ & 14 & 2.27 & 0.22 & ${ }^{12} \mathrm{LiBr}$ & 16 & 4.94 & 0.02 \\
\hline${ }^{12} \mathrm{Ca}\left(\mathrm{NO}_{3}\right)_{2}$ & 11 & 2.03 & 0.07 & ${ }^{12,14} \mathrm{LiCl}$ & 19 & 5.90 & 0.12 \\
\hline${ }^{12} \mathrm{CdBr}_{2}$ & 11 & 2.45 & 0.16 & ${ }^{12} \mathrm{LiI}$ & 18 & 4.98 & 0.11 \\
\hline${ }^{12,15,16} \mathrm{CdCl}_{2}$ & 37 & 5.86 & 0.08 & ${ }^{12} \mathrm{LiIO}_{3}$ & 15 & 3.33 & 0.02 \\
\hline${ }^{13} \mathrm{Cd}\left(\mathrm{NO}_{3}\right)_{2}$ & 5 & 1.50 & 0.33 & ${ }^{12} \mathrm{LiNO}_{3}$ & 15 & 5.64 & 0.09 \\
\hline${ }^{16} \mathrm{CdI}_{2}$ & 15 & 2.23 & 0.14 & ${ }^{12,18} \mathrm{LiOH}$ & 18 & 4.64 & 0.03 \\
\hline${ }^{16} \mathrm{CoCl}_{2}$ & 12 & 2.88 & 0.05 & ${ }^{12} \mathrm{Li}_{2} \mathrm{SO}_{4}$ & 10 & 2.00 & 0.23 \\
\hline${ }^{17} \mathrm{Co}\left(\mathrm{NO}_{3}\right)_{2}$ & 5 & 5.47 & 0.10 & ${ }^{12} \mathrm{MgBr}_{2}$ & 15 & 4.44 & 0.07 \\
\hline${ }^{12} \mathrm{CsBr}$ & 21 & 5.74 & 0.07 & ${ }^{12,13} \mathrm{MgCl}_{2}$ & 27 & 5.00 & 0.10 \\
\hline${ }^{12} \mathrm{CsCl}$ & 19 & 4.86 & 0.02 & ${ }^{17} \mathrm{Mg}\left(\mathrm{ClO}_{4}\right)_{2}$ & 4 & 3.77 & 0.05 \\
\hline${ }^{12} \mathrm{CsI}$ & 20 & 3.85 & 0.05 & ${ }^{12} \mathrm{MgI}_{2}$ & 13 & 1.94 & 0.20 \\
\hline${ }^{12} \mathrm{CsNO}_{3}$ & 8 & 0.84 & 0.01 & ${ }^{12} \mathrm{Mg}\left(\mathrm{NO}_{3}\right)_{2}$ & 12 & 2.13 & 0.17 \\
\hline${ }^{12} \mathrm{Cs}_{2} \mathrm{SO}_{4}$ & 14 & 0.97 & 0.06 & ${ }^{12} \mathrm{MgSO}_{4}$ & 13 & 2.92 & 0.18 \\
\hline${ }^{12} \mathrm{CuCl}_{2}$ & 11 & 1.86 & 0.04 & ${ }^{15,16} \mathrm{MnCl}_{2}$ & 32 & 5.42 & 0.08 \\
\hline${ }^{12} \mathrm{CuSO}_{4}$ & 7 & 0.85 & 0.07 & ${ }^{12} \mathrm{MnSO}_{4}$ & 16 & 2.84 & 0.14 \\
\hline${ }^{12} \mathrm{FeCl}_{3}$ & 15 & 4.11 & 0.07 & ${ }^{12} \mathrm{NH}_{4} \mathrm{Cl}$ & 13 & 5.90 & 0.20 \\
\hline${ }^{12} \mathrm{HgCl}_{2}$ & 5 & 0.19 & 0.00 & ${ }^{12} \mathrm{NH}_{4} \mathrm{NO}_{3}$ & 16 & 5.35 & 0.02 \\
\hline${ }^{12,13} \mathrm{KBr}$ & 25 & 5.60 & 0.07 & ${ }^{12}\left(\mathrm{NH}_{4}\right)_{2} \mathrm{SO}_{4}$ & 18 & 5.04 & 0.13 \\
\hline${ }^{12} \mathrm{KBrO}_{3}$ & 5 & 0.32 & 0.01 & ${ }^{12,13,14} \mathrm{NaBr}$ & 30 & 5.23 & 0.09 \\
\hline${ }^{12} \mathrm{~K}_{2} \mathrm{CO}_{3}$ & 18 & 4.82 & 0.09 & ${ }^{12,14} \mathrm{NaCl}$ & 21 & 5.40 & 0.05 \\
\hline${ }^{12,14} \mathrm{KCl}$ & 21 & 4.71 & 0.04 & ${ }^{12} \mathrm{Na}_{2} \mathrm{CO}_{3}$ & 8 & 1.54 & 0.13 \\
\hline${ }^{12} \mathrm{KClO}_{3}$ & 4 & 0.34 & 0.01 & ${ }^{12} \mathrm{NaHSO}_{4}$ & 12 & 2.35 & 0.09 \\
\hline${ }^{12} \mathrm{KHCO}_{3}$ & 3 & 0.42 & 0.01 & ${ }^{12} \mathrm{NaI}$ & 19 & 5.46 & 0.05 \\
\hline${ }^{12} \mathrm{KH}_{2} \mathrm{PO}_{4}$ & 8 & 1.20 & 0.04 & ${ }^{17} \mathrm{Na}_{2} \mathrm{MoO}_{4}$ & 5 & 2.61 & 0.02 \\
\hline
\end{tabular}


Table 3. (Continuation)

\begin{tabular}{|c|c|c|c|c|c|c|c|}
\hline SALT & $\mathbf{N}_{\text {DATA }}$ & $\begin{array}{c}\mathbf{I}_{\mathbf{M A X}} \\
\mathrm{mol} \mathrm{kg}^{-1}\end{array}$ & $\% \mathrm{AD}$ & Salt & $\mathbf{N}_{\text {DATA }}$ & $\begin{array}{c}\mathbf{I}_{\mathbf{M A X}} \\
\mathrm{mol} \mathrm{kg}^{-1}\end{array}$ & $\% A D$ \\
\hline${ }^{12} \mathrm{KHSO}_{4}$ & 9 & 1.40 & 0.11 & ${ }^{12} \mathrm{NaN}_{3}$ & 14 & 5.40 & 0.04 \\
\hline${ }^{12} \mathrm{KI}$ & 19 & 4.93 & 0.06 & ${ }^{12} \mathrm{NaNO}_{3}$ & 16 & 5.04 & 0.08 \\
\hline${ }^{12} \mathrm{KIO}_{3}$ & 3 & 0.14 & 0.00 & ${ }^{16} \mathrm{NaOH}$ & 11 & 3.01 & 0.05 \\
\hline${ }^{12} \mathrm{KN}_{3}$ & 17 & 5.80 & 0.02 & ${ }^{17} \mathrm{Na}_{2} \mathrm{SO}_{3}$ & 4 & 1.98 & 0.07 \\
\hline${ }^{12,13,17} \mathrm{Na}_{2} \mathrm{SO}_{4}$ & 20 & 2,22 & 0,10 & ${ }^{12} \mathrm{SrBr}_{2}$ & 15 & 3,31 & 0,13 \\
\hline${ }^{16} \mathrm{NiCl}_{2}$ & 12 & 2,89 & 0,02 & ${ }^{12,13} \mathrm{SrCl}_{2}$ & 18 & 3,40 & 0,07 \\
\hline${ }^{12} \mathrm{~Pb}\left(\mathrm{NO}_{3}\right)_{2}$ & 16 & 1,29 & 0,06 & ${ }^{12} \mathrm{SrI}_{2}$ & 15 & 2,40 & 0,08 \\
\hline${ }^{12} \mathrm{RbBr}$ & 19 & 4,95 & 0,10 & ${ }^{12} \mathrm{TINO}_{3}$ & 7 & 0,28 & 0,01 \\
\hline${ }^{12} \mathrm{RbCl}$ & 18 & 5,51 & 0,02 & ${ }^{12} \mathrm{Tl}_{2} \mathrm{SO}_{4}$ & 4 & 0,08 & 0,02 \\
\hline${ }^{12} \mathrm{RbI}$ & 21 & 5,76 & 0,04 & ${ }^{12} \mathrm{ZnBr}_{2}$ & 17 & 5,43 & 0,31 \\
\hline${ }^{12} \mathrm{RbNO}_{3}$ & 17 & 3,19 & 0,04 & ${ }^{12,15,16} \mathrm{ZnCl}_{2}$ & 63 & 5,50 & 0,22 \\
\hline${ }^{12} \mathrm{Rb}_{2} \mathrm{SO}_{4}$ & 17 & 1,76 & 0,08 & & & & \\
\hline
\end{tabular}

Table 4. Deviations in the prediction of the density in multicomponent systems at $298.15 \mathrm{~K}$

\begin{tabular}{|c|c|c|c|}
\hline System & $\mathbf{N}_{\text {DATA }}$ & $\begin{array}{c}\mathbf{I}_{\mathrm{MAX}} \\
\mathrm{mol} \mathrm{\textrm {kg } ^ { - 1 }}\end{array}$ & $\begin{array}{c}\text { AD } \\
\%\end{array}$ \\
\hline${ }^{19} \mathrm{BaCl}_{2}-\mathrm{NaCl}-\mathrm{H}_{2} \mathrm{O}$ & 44 & 4.50 & 0.08 \\
\hline${ }^{20} \mathrm{CaCl}_{2}-\mathrm{KCl}-\mathrm{H}_{2} \mathrm{O}$ & 44 & 4.50 & 0.09 \\
\hline${ }^{21} \mathrm{CaCl}_{2}-\mathrm{NaCl}-\mathrm{H}_{2} \mathrm{O}$ & 78 & 9.74 & 0.03 \\
\hline${ }^{22} \mathrm{KBr}-\mathrm{NaCl}-\mathrm{H}_{2} \mathrm{O}$ & 6 & 3.00 & 0.17 \\
\hline${ }^{23} \mathrm{KCl}-\mathrm{MgCl}_{2}-\mathrm{H}_{2} \mathrm{O}$ & 46 & 4.50 & 0.07 \\
\hline${ }^{24} \mathrm{KCl}-\mathrm{NaBr}-\mathrm{H}_{2} \mathrm{O}$ & 41 & 4.00 & 0.05 \\
\hline${ }^{22} \mathrm{KCl}-\mathrm{NaCl}-\mathrm{H}_{2} \mathrm{O}$ & 6 & 5.00 & 0.08 \\
\hline${ }^{25} \mathrm{KCl}-\mathrm{NaCl}-\mathrm{H}_{2} \mathrm{O}$ & 7 & 1.50 & 0.02 \\
\hline${ }^{22} \mathrm{KCl}-\left(\mathrm{NH}_{4}\right)_{2} \mathrm{SO}_{4}-\mathrm{H}_{2} \mathrm{O}$ & 6 & 3.50 & 0.05 \\
\hline${ }^{25} \mathrm{KCl}-\mathrm{K}_{2} \mathrm{SO}_{4}-\mathrm{H}_{2} \mathrm{O}$ & 11 & 1.50 & 0.16 \\
\hline${ }^{25} \mathrm{KCl}-\mathrm{Na}_{2} \mathrm{SO}_{4}-\mathrm{H}_{2} \mathrm{O}$ & 11 & 1.50 & 0.06 \\
\hline${ }^{25} \mathrm{~K}_{2} \mathrm{SO}_{4}-\mathrm{Na}_{2} \mathrm{SO}_{4}-\mathrm{H}_{2} \mathrm{O}$ & 11 & 1.50 & 0.16 \\
\hline${ }^{18} \mathrm{La}\left(\mathrm{NO}_{3}\right)_{3}-\mathrm{Mg}\left(\mathrm{NO}_{3}\right)_{2}-\mathrm{H}_{2} \mathrm{O}$ & 19 & 17.05 & 0.31 \\
\hline${ }^{22}\left(\mathrm{NH}_{4}\right)_{2} \mathrm{SO}_{4}-\mathrm{Na}_{2} \mathrm{SO}_{4}-\mathrm{H}_{2} \mathrm{O}$ & 6 & 9.00 & 0.12 \\
\hline${ }^{25} \mathrm{NaCl}-\mathrm{Na}_{2} \mathrm{SO}_{4}-\mathrm{H}_{2} \mathrm{O}$ & 10 & 1.50 & 0.08 \\
\hline${ }^{25} \mathrm{NaCl}-\mathrm{K}_{2} \mathrm{SO}_{4}-\mathrm{H}_{2} \mathrm{O}$ & 11 & 1.50 & 0.06 \\
\hline${ }^{26} \mathrm{CaCl}_{2}-\mathrm{KCl}-\mathrm{MgCl}_{2}-\mathrm{NaCl}-\mathrm{H}_{2} \mathrm{O}$ & 9 & 9.23 & 0.23 \\
\hline
\end{tabular}


Table 5. Deviations in the calculation of densities of aqueous systems at $298.15 \mathrm{~K}$

\begin{tabular}{|l|l|l|l|l|l|l|}
\hline Aqueous System & $\mathrm{N}_{\text {DATA }}$ & $\mathrm{I}_{\max }$ & Eq.11 & $\begin{array}{l}\mathrm{P}- \\
\mathrm{K}^{(8)}\end{array}$ & Pitzer $^{(11)}$ & $\mathrm{T} \mathrm{G}^{(10)}$ \\
\hline${ }^{20} \mathrm{CaCl}_{2}-\mathrm{KCl}$ & 44 & 4.50 & 0.07 & 0.04 & 0.15 & 0.26 \\
\hline${ }^{21} \mathrm{CaCl}_{2}-\mathrm{NaCl}$ & 78 & 9.74 & 0.03 & 0.06 & 0.20 & 0.43 \\
\hline${ }^{23} \mathrm{KCl}-\mathrm{MgCl}_{2}$ & 46 & 4.50 & 0.06 & 0.04 & 0.12 & 0.22 \\
\hline${ }^{22} \mathrm{KCl}-\mathrm{NaCl}$ & 6 & 5.00 & 0.08 & 0.10 & 0.26 & 0.63 \\
\hline${ }^{25} \mathrm{KCl}-\mathrm{NaCl}^{25}$ & 7 & 1.50 & 0.02 & 0.03 & 0.06 & 0.35 \\
\hline${ }^{25 C l}-\mathrm{Na}_{2} \mathrm{SO}_{4}$ & 11 & 1.50 & 0.05 & 0.02 & 0.10 & 0.14 \\
\hline${ }^{25} \mathrm{NaCl}-\mathrm{Na}_{2} \mathrm{SO}_{4}$ & 10 & 1.50 & 0.01 & 0.01 & 0.07 & 0.13 \\
\hline $\begin{array}{l}{ }^{26} \mathrm{CaCl} \\
\mathrm{KCl}_{2}-\mathrm{MgCl}_{2}-\end{array}$ & 9 & 9.23 & 0.21 & 0.30 & 0.90 & 0.24 \\
\hline
\end{tabular}

\section{CONCLUSIONS}

A new methodology is presented for the calculation of density of simple and multicomponent aqueous saline systems. The proposed equation was found to be appropriate for predicting the densities in these systems. Comparisons of the deviations obtained between the proposed methods and other models both in low and high concentration zones demonstrated that this new method was satisfactory.

Parameters for the new model were determined for 38 ions, which were obtained from 1192 experimental data representing 81 binary aqueous systems at 298.15. Values for absolute mean deviation ranged from zero to

$0.33 \%$. In the prediction of 366 experimental points representing 17 multicomponent systems, the mean absolute deviations obtained were between 0.03 and $0.31 \%$, demonstrating an excellent representation of the density using the proposed model.

We have seen that the information contained in equation (10) represents to contributions of the species in solution, $\alpha_{i}$ and $v^{0}$, Both of which are empirical parameters obtained from experimental information. As observed in Table 2 , based on the units of $\alpha_{i}$ and $v^{0}$, these parameters can be interpreted as contributions to the molar ionic volume. In agreement with the preceding, the values for group IA ions are found in the expected order, that is $\mathrm{Li}^{+}<\mathrm{Na}^{+}<\mathrm{K}^{+}$ $<\mathrm{Rb}^{+}<\mathrm{Cs}$. Nevertheless, a lower value is found among ions in group IIA. This may be attributable to the contribution of parameter $\alpha_{i}$ which increases significantly, and thus contributes to the increase in molar volume.

In general, the experimental data obtained from the literature were in agreement with the results obtained with the extended method proposed, thus supporting the general validity of the technique of estimation developed in this study

\section{List of Symbols}

$\%$ AD mean percent deviation

I ionic strength $\left[\mathrm{mol} \mathrm{kg}^{-1}\right]$

M Molar mass of medium

$\mathrm{M}_{\mathrm{i}} \quad$ Molar mass of species $\mathrm{i}$

$\mathrm{M}_{\mathrm{w}}^{\mathrm{i}} \quad$ Molar mass of water

$\mathrm{n}_{\mathrm{s}} \quad$ number of moles of electrolytes [mol]

$\mathrm{n}_{\mathrm{w}} \quad$ number of moles of water [mol]

$\mathrm{N}_{\text {ION }}$ total number of ionic species

$\mathrm{N}_{\text {DATA }}$ number of experimental data

O.F. objective function

P-K Patwardhan-Kumar

T-G Theliander-Grén

$v \quad$ molar volume $\left[\mathrm{cm}^{3} \mathrm{~mol}^{-1}\right]$ empirical parameters, anionic, Table $2\left[\mathrm{~cm}^{3} \mathrm{~mol}^{-1}\right]$

.o empirical parameters, cationic, Table $2\left[\mathrm{~cm}^{3} \mathrm{~mol}^{-1}\right]$

-.o molar volume, electrolyte $\left[\mathrm{cm}^{3} \mathrm{~mol}^{-1}\right]$

$v_{w}^{o}$ molar volume, water $\left[\mathrm{cm}^{3} \mathrm{~mol}^{-1}\right]$

$\mathrm{x}^{w}$

\section{Greek letters}

$\alpha \quad$ empirical parameter $\left[\mathrm{cm}^{3} \mathrm{~mol}^{-1}\right]$

$\alpha$ : empirical parameter, Table $2\left[\mathrm{~cm}^{3} \mathrm{~mol}^{-1}\right]$

$\rho$ density $\left[\mathrm{g} \mathrm{cm}^{-3}\right]$

$v \quad$ stoichiometric coefficient

Subscripts

A anion

C cation

exp. Experimental value

i ionic species

max maximum

s solute

w water

\section{REFERENCES}

1. Horsák, I., and Sláma, I. J. Chem. Eng. Data, 31(4), 434, (1986)

2. Hu, Y-F. J. Sol. Chem. 29(1), 1229, (2000)

3. Krumgalz, B.S., Pogorelsky.,R., and Pitzer, K. J. Phys. Chem. Ref. Data, 25(2), 663 .

4. Heyrovská, R. (1996) J. Electrochem. Soc., 143(6),1789. (1996).

5. Yu, Y-X., Gao.,G-H., Daridon, J-L., and Lagourette, B.(2003) Fluid Phase Equil. 206, 205, (1996)

6. Horvath, A.L. Handbook of Aqueous Electrolyte Solutions: Physical Properties. Estimation and Correlation Methods. Wiley, Chichester, 106$145,1985$.

7. Li, C-X.,Park,S.B., Kim,J-S., and Lee, H. Fluid Phase Equilibria, 145, 1-14, (1998)

8. Patwardhan, V., and Kumar, A. AICHE J., 32(9), 1429, (1986)

9. Iulian, O., and Sîrbu, F. Revue Roumaine de Chimie, 50(11-12), 1027 (2005)

10. Theilander,H., and Grén, U. Computers Chem. Eng. 13(45),419-424, (1989)

11. Kumar, A. J. Chem. Eng. Data, 31(1), 19, (1986)

12. International Critical Table of Numerical Data, Physics, Chemistry and Technology, New York, McGraw Hill Book Company, Vol. III, 1928.

13. Isono, T. J. Chem. Eng. Data, 29(1), 45, (1984)

14. Gates, J.A. and Wood, R.H. J. Chem. Eng. Data, 30 (1), 44, (1985)

15. Rard, J.A. and Miller, D.G. J. Chem. Eng. Data, 29(2), 151, (1984)

16. Herrington, T.M., Roffey, M.G., Smith, D.P. J. Chem. Eng. Data, 31(2), 221, (1984)

17. Novotny, P., Söhnel, O., and Solc, Z. J. Chem. Eng. Data, 29(4), 379, (1984)

18. Clark, D., Rafal, M., Scrivner, N., Zemaitis, J. F. Handbook of Aqueous Electrolyte Thermodynamics, $1^{\text {a }}$ Edición, pp. 560-562, New York, U.S.A., 1986

19. Manohar, S., Puchalska, D., Atkinson, G. J. Chem. Eng. Data, 39(19), 150, (1994)

20. Kumar, A. J. Chem. Eng. Data, 31(1), 21, (1986)

21. Oakes, Ch. S., Simonson, J. M., Bodnar, R. J. J. Chem. Eng. Data, 35(3), 304, (1990)

22. Goldsack, D., Franchetto, A. Electrichimica Acta, 22 (11), 1287, (1986)

23. Kumar, A. J. Chem. Eng. Data, 34(1), 87, (1989)

24. Kumar, A. J. Chem. Eng. Data, 34(4),446, (1989)

25. Millero, F.J., Sotolongo, S. J. Chem. Eng. Data, 31(4), 470, (1986)

26. Krumgalz, B.S., Millero, F.J. Mar. Chem. 11(5), 477, (1982) 